\title{
Teaching Theory in Applied Degrees: A Critical Examination of Curricular Design for Translation Theory Subjects in Comparison with the Students' Expectations
}

\author{
Ordóñez-López, Pilar ${ }^{a}$ and Agost, Rosa ${ }^{\text {b }}$
}

${ }^{\mathrm{a}}$ Department of Translation and Communication, University Jaume I, Spain, ${ }^{\mathrm{b}}$ Department of Translation and Communication, University Jaume I, Spain.

\begin{abstract}
Due to the practice-oriented nature of Translation and Interpreting study programmes, students are generally assumed to have a reluctant attitude towards the study of theory. However, previous empirical research allows us to dispel this myth: students are aware of the contribution of translation theory to their education as future translators. Taking into account students' needs and expectations, in this paper emphasis is placed on curricular design. A critical examination of the syllabi of Translation Theory subjects, focusing on learning outcomes and teaching methodology, reveals some (mis)matches between teaching planning and the students' expectations. The results obtained show a relatively high degree of coincidence between these two aspects on the one hand, while also highlighting some inaccuracies in the teaching planning of these subjects on the other. These two aspects should be considered a starting point for a revision of the curricular design in order to present an accurate description of the subject by means of an adequate explanation of the intended learning outcomes and teaching methodology, and in order to provide students with significant and useful insights into the theoretical dimension of translation.
\end{abstract}

Keywords: Translation Study Programmes; Translation Theory Teaching; Curricular Design; Students' Expectations. 


\section{Introduction}

Degrees in Translation and Interpreting are usually very practice-oriented, as a result of a number of reasons among which the nature of translation (an applied activity) and the socio-cultural context in which the institutionalization of these studies took place (cf. Vega and Pulido, 2013: 45) can be cited. The applied, market-oriented character of translation study programmes is, at the same time, their main appeal; it is common for students to choose to embark themselves in translation and interpreting study programmes attracted by their innovative, up-to-date as far as the professional market is concerned, and applied approach, in comparison to more traditional philological degrees. Nevertheless, without leaving the inherent applied nature of translation aside, it is precisely the development of theoretical approaches which has allowed the practice of translation to be analysed in a systematic manner and has contributed to the consolidation of Translation Studies as an independent academic discipline. Therefore, it is only natural to expect that theoretical reflection (theoretical models, approaches, basic theoretical concepts of the discipline, metalanguage, etc.) is incorporated into translation and interpreting study programmes. However, a review of the study programmes offered at Spanish universities reveal that translation theory occupies a marginal role in the education of translator and interpreters to be (cf. Agost and Ordóñez-López, 2016).

The interconnection between translation theory and the actual activity of translation has still not been fully accepted in the professional, academic or training contexts. Within the Translation Studies literature, numerous scholars have outlined the benefits of more holistic and humanistic study programmes as well as the contribution that such training would make to the professional context and the discipline as a whole (Delisle, 1981; Gile, 1995, 2010; Mossop, 2003; Malmkjær, 2006; Agost, 2008). Besides, despite the wide-spread belief that students lack interest in theoretical subjects, the results obtained in previous empirical studies (cf. Ordóñez-López and Agost, 2014 and Agost and Ordóñez-López, 2015) allow us to dispel this myth. Translation and Interpreting students are not reluctant to theory, they are aware of the contribution of theoretical subjects to their training. In fact, they do not establish a clear-cut division between the theory and the practice of translation, which becomes especially apparent when dealing with methodological issues and with the acquisition of the discipline metalanguage.

Based on our previous research, in this paper emphasis is placed on curricular design, more specifically on examining to what extent students needs and expectations are being met regarding learning outcomes and teaching methodology. In what follows, a critical examination of the syllabi of Translation Theory subjects in comparison to the students' perceived needs is carried out. This examination will reveal the aspects in which (mis)matches can be found, which should be considered a starting point for a revision of the planning and curricular design of Translation Theory subjects. 


\section{Expected Learning Outcomes in Translation Theory Subjects}

Among the changes resulting from the Bologna process and the implementation of the European Higher Education Area is the adoption of a new approach concerning teaching planning as well as the actual performance of teaching, i.e., the roles adopted by both the teacher and the students, in and out of the classroom. Without going into further discussion, as the rationale of this new approach and the main changes involved have already been extensively discussed, the shift of focus from the teacher to the student implied the incorporation of "learning outcomes" into teaching planning, instead of using the more traditional concept of "objectives".

The learning outcomes are statements of what students are expected to know, understand and/or be able to do at the end of their degree programme. The adequate definition of learning outcomes makes it possible to inform society and the students of the learning requirementss established for each level; furthermore, learning outcomes provide employers with information about prospective employees' skills. $\left(\right.$ ANECA, 2013) ${ }^{1}$

\subsection{Intended Learning Outcomes in Translation Theory Syllabi}

As stated in the previous definition, an adequate description of the learning outcomes enables students to get a (more or less) accurate idea of the rationale of a subject as well as its contribution to their training as future professionals. In spite of its limitations, due mainly to administrative and technical reasons, a review of the syllabi of Translation Theory subjects taught at Spanish universities in Translation degrees should thus provide relevant insights into the learning outcomes lecturers expect students to achieve.

Table 1 shows the intended learning outcomes ${ }^{2}$ most frequently included in the syllabi of Translation Theory subjects ${ }^{3}$, which reveal the existence of some confusion in the conceptual level regarding the identification of the object of study of translation theory; for instance, the acquisition of information seeking techniques (included in $63,6 \%$ of the syllabi) can hardly be directly related with the study of the theoretical component of translation. Furthermore, it is noteworthy the fact that the majority of the intended learning outcomes fail to contribute to reinforcement the existing connection between the theory and the practice of translation.

\footnotetext{
1 Our translation.

2 It should be noted that in the examination of the learning outcomes stated in the syllabi only those considered specific to the subject (competencias específicas) were taken into consideration.

3 There is a total of 22 subjects dedicated to translation theory (Agost and Ordóñez-López, 2016), according to the information provided on the webpages of the 24 universities which currently offer undergraduate study programmes in translation in Spain.
} 
Table 1. Intended learning outcomes in Translation Theory Syllabi

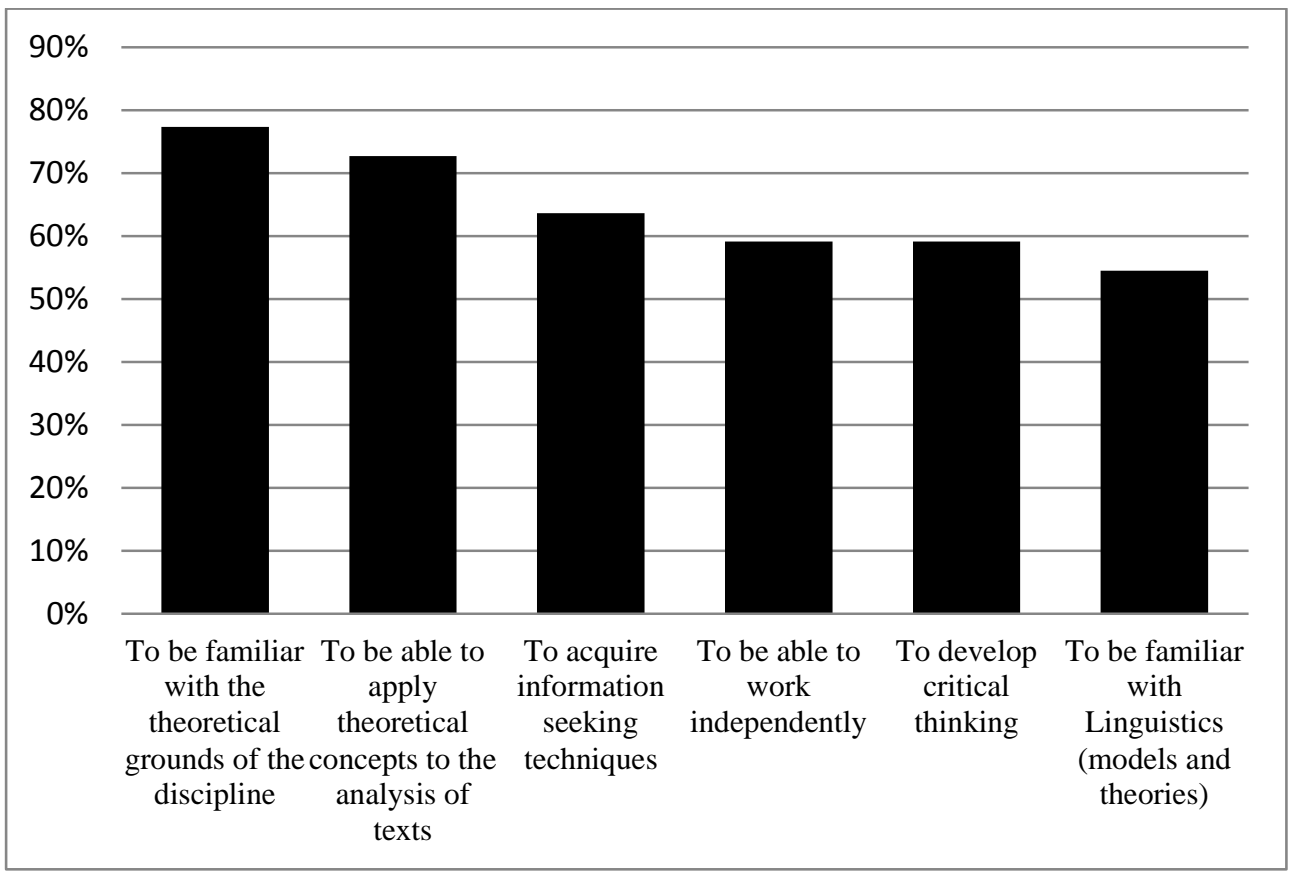

\subsection{Students' Expected learning Outcomes in Translation Theory Subjects}

In an empirical study conducted at four Spanish universities ${ }^{4}$ (cf. Ordóñez-López and Agost, 2014 and Agost and Ordóñez-López, 2015), with a population of over 900 students, respondents were asked about what they consider to be the most important learning outcomes in theoretical subjects.

As shown in Table 2, the majority of students expect to acquire the competences which enable them to deal with translation problems and solutions $(38.3 \%)$, followed by a good knowledge of both the field and the development of the discipline $(20.8 \%)$. If level of studies is taken as the independent variable, one more interesting tendency emerges: students in their fourth year and those doing a research-based master's course give more importance to critical thinking (25.5\% and $23.1 \%$, respectively).

\footnotetext{
4 The informants were mainly undergraduate students and, to a more limited extent, postgraduate students, at four Spanish universities: the University of Granada, the University of Alicante, the Autonomous University of Barcelona and the University Jaume I.
} 
Table 2. The most important learning outcomes according to students

\begin{tabular}{|l|c|c|c|c|c|c|c|c|c|c|}
\hline & $\begin{array}{c}\text { 1st } \\
\text { year }\end{array}$ & $\begin{array}{l}\text { 2nd } \\
\text { year }\end{array}$ & $\begin{array}{c}\text { 3rd } \\
\text { year }\end{array}$ & $\begin{array}{c}4 \text { th } \\
\text { year }\end{array}$ & MRes & MA & PhD & $\begin{array}{c}\text { Erasmus/ } \\
\text { exchange }\end{array}$ & $\begin{array}{c}\text { No } \\
\text { answer }\end{array}$ & Total \\
\hline $\begin{array}{l}\text { Familiarise } \\
\text { themselves with } \\
\text { the discipline and } \\
\text { its evolution }\end{array}$ & 39 & 53 & 55 & 39 & 3 & 2 & 0 & 2 & 0 & $\mathbf{1 9 3}$ \\
\hline $\begin{array}{l}\text { Develop critical } \\
\text { thinking }\end{array}$ & 18 & 31 & 38 & 37 & 3 & 1 & 0 & 0 & 0 & $\mathbf{1 2 8}$ \\
\hline $\begin{array}{l}\text { Systematise } \\
\text { translation } \\
\text { problems and } \\
\text { solutions }\end{array}$ & 120 & 104 & 78 & 38 & 3 & 4 & 0 & 8 & 0 & $\mathbf{3 5 5}$ \\
\hline $\begin{array}{l}\text { Analyse } \\
\text { translations (their } \\
\text { own and others') } \\
\text { using } \\
\text { appropriate the } \\
\text { terminology }\end{array}$ & 52 & 43 & 17 & 12 & 1 & 3 & 2 & 0 & 0 & $\mathbf{1 3 0}$ \\
\hline Other & 16 & 12 & 15 & 15 & 3 & 0 & 0 & 0 & 1 & $\mathbf{7 2}$ \\
\hline No answer & 24 & 22 & 6 & 4 & 0 & 0 & 1 & 1 & 0 & $\mathbf{5 8}$ \\
\hline Total & $\mathbf{2 6 9}$ & $\mathbf{2 6 5}$ & $\mathbf{2 0 9}$ & $\mathbf{1 4 5}$ & $\mathbf{1 3}$ & $\mathbf{1 0}$ & $\mathbf{3}$ & $\mathbf{1 1}$ & $\mathbf{1}$ & $\mathbf{9 2 6}$ \\
\hline
\end{tabular}

\section{Methodology in Translation Theory Subjects}

Teaching methodology is a key aspect in keeping students motivated; given the fact that translation degree programmes tend to be practice-oriented, it is even more important when it comes to the teaching of theoretical subjects to apply an appropriate methodology. The inherent applied nature of translation should be taken into consideration in order to adopt an adequate methodology, as well as appealing and relevant classroom activities. Again, the application of new teaching paradigms with the implementation of the principles guiding the EHA (European Higher Education Area), has involved the adoption of new methodologies which contribute to the development of a leading role by students, who should be enabled to construct and manage their learning process.

\subsection{Intended Methodology in Translation Theory Teaching Planning}

As shown in Table 3, the review of the syllabi of Translation Theory subjects reveals that the majority of lecturers applied a mixed methodology, combining traditional lectures (in some cases it is specifically stated that students' participation is encouraged) with practical sessions, which normally favour more active participation of students. Comparatively little attention is paid to tutorial session, which only appear in $41 \%$ of the syllabi examined, despite the relevance of this teaching method in the methodological shift experienced with the implementation of the Bologna process. Furthermore, it is important to mention that, in 
some cases, when performing activities involving translations ${ }^{5}$, the translation itself is considered the main aim of the activity, rather than using translation as a means to raise the students' awareness of the theoretical models, strategies, methods, techniques, etc. that operate in the act of translating. It is precisely this aspect that makes the difference between a (general or specialised) translation class and a translation theory class.

Table 3. Teaching/learning activities in Translation Theory syllabi

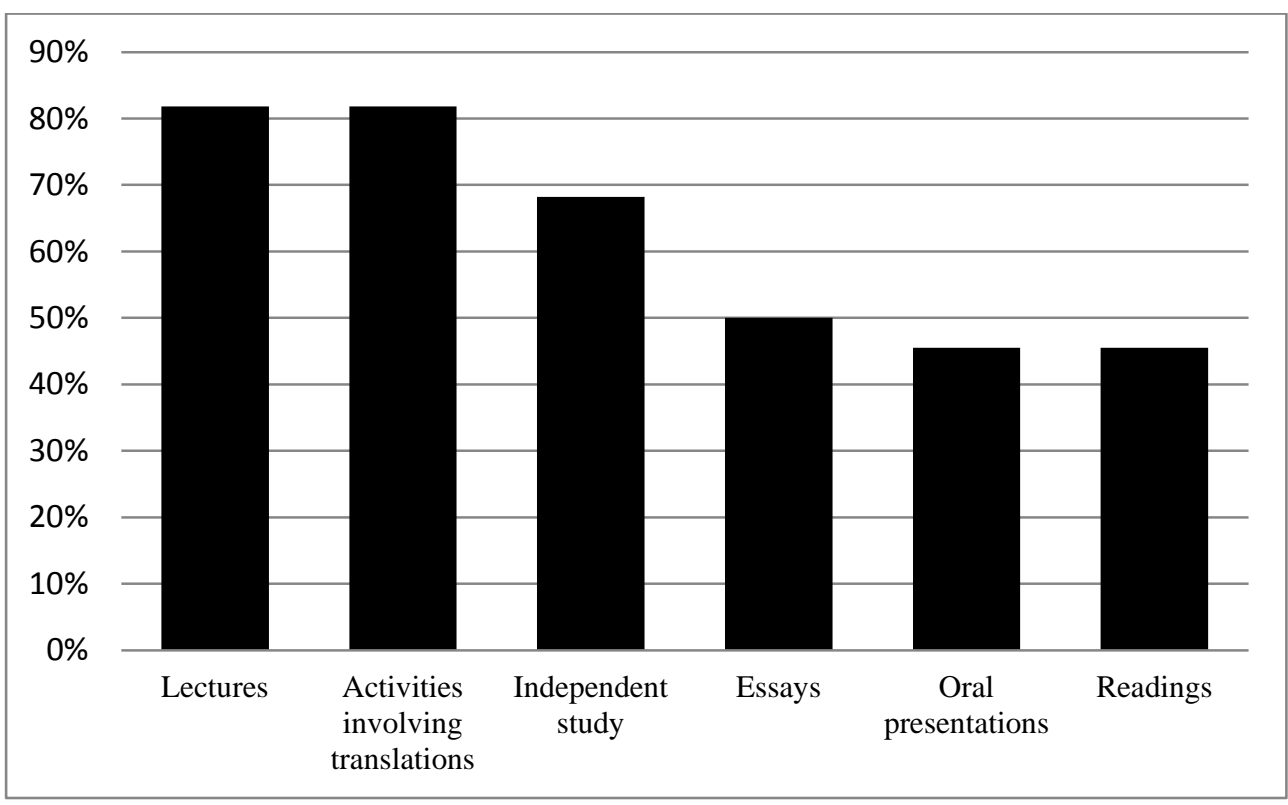

\subsection{Students' Expected Methodology in Translation Theory Subjects}

First of all, according to the results obtained in our previous investigation (cf. OrdóñezLópez and Agost, 2014), generally speaking, the majority of students perceive their role as being adequate, although $25.7 \%$ rate it as passive. Although these data should be compared with those from other subjects to get a more accurate impression, they suggest that there is room for improvement.

As shown in Table $4,35.1 \%$ of the respondents prefer to carry out activities involving translations, followed by debates (19.3\%), which require a higher level of cognitive demands and critical thinking from students. However, a significant degree of rejection of other activities that are also very taxing from this point of view, but which are carried out individually or outside the classroom, as part of the students' personal workload (such as reading, $7.6 \%$; assignments or essay writing, $5 \%$; reviews, $0.6 \%$ ) can be observed.

\footnotetext{
5 The exact nature of these activities cannot be determined from the information included in the syllabi.
} 
Table 4. Students' expected teaching activities in Translation Theory subjects

\begin{tabular}{|c|c|c|c|c|c|c|c|c|c|c|}
\hline \multirow[b]{2}{*}{$\begin{array}{c}\text { Level of } \\
\text { studies }\end{array}$} & \multicolumn{9}{|c|}{ Preferred teaching activity in Translation Theory subjects } & \multirow[b]{2}{*}{ Total } \\
\hline & $\begin{array}{c}1 \text { st } \\
\text { year }\end{array}$ & $\begin{array}{l}2 \mathrm{nd} \\
\text { year }\end{array}$ & $\begin{array}{l}3 \mathrm{rd} \\
\text { year }\end{array}$ & $\begin{array}{l}4 \text { th } \\
\text { year }\end{array}$ & MRes & MA & $\mathrm{PhD}$ & $\begin{array}{l}\text { Erasmus/ } \\
\text { Exchange }\end{array}$ & $\begin{array}{c}\text { No } \\
\text { answer }\end{array}$ & \\
\hline Readings & 18 & 20 & 19 & 6 & 4 & 3 & 0 & 0 & 0 & 70 \\
\hline Debate & 43 & 45 & 37 & 48 & 0 & 2 & 0 & 4 & 0 & 179 \\
\hline $\begin{array}{l}\text { Online } \\
\text { forums }\end{array}$ & 6 & 4 & 1 & 1 & 0 & 1 & 1 & 0 & 0 & 14 \\
\hline Reviews & 3 & 1 & 2 & 0 & 0 & 0 & 0 & 0 & 0 & 6 \\
\hline $\begin{array}{c}\text { Oral } \\
\text { presentations }\end{array}$ & 11 & 6 & 7 & 4 & 0 & 1 & 0 & 1 & 0 & 30 \\
\hline Essay & 14 & 15 & 13 & 2 & 0 & 0 & 0 & 2 & 0 & 46 \\
\hline Text analysis & 6 & 12 & 3 & 5 & 0 & 1 & 0 & 0 & 0 & 26 \\
\hline $\begin{array}{c}\text { Exercises } \\
\text { involving } \\
\text { translations }\end{array}$ & 98 & 113 & 82 & 28 & 1 & 2 & 0 & 1 & 0 & 325 \\
\hline Other & 69 & 38 & 43 & 50 & 8 & 0 & 1 & 3 & 1 & 213 \\
\hline No answer & 1 & 11 & 3 & 1 & 0 & 0 & 1 & 0 & 0 & 17 \\
\hline Total & 269 & 265 & 210 & 145 & 13 & 10 & 3 & 11 & 1 & 927 \\
\hline
\end{tabular}

\section{Discussion}

Given the fact that translation study programmes are predominantly practice-oriented, the teaching of theoretical subjects can be challenging and demanding. Taken into consideration both the two-fold nature of Translation Studies and the students' expectations, efforts should be made to facilitate the successful integration of theoretical contents into the education of translators-to-be in the teaching planning (and subsequent implementation).

The results obtained in the examination of the syllabi of subjects on Translation Theory taught at Spanish universities reveal the existence of some problems, of an epistemic nature, related to the identification of the object of study of theoretical subjects. Furthermore, some teaching methods make it more difficult for students to adopt a central role and to perceive translation theory and practice as two interconnected dimensions of Translation Studies.

Concerning the (mis)match between the intended learning outcomes and teaching methods, on the one hand, and students' expectations regarding these two aspects on the other, considerable coincidence can be observed. "Being familiar with the theoretical grounds of the discipline" is the most frequent learning outcome in the syllabi and is also one of the most important aspects for students; however, some learning outcomes directly related with the professional practice of translation, such as the analysis of translations (their own and others') using the adequate metalanguage, appear to receive little attention in the teaching planning. With regards to methodology, "lectures" is the most commonly used method, although students' expectations privilege more applied and participative classroom activities, such as working with translations. 
To sum up, in spite of the relative similarity between the students' expectations and Translation Theory teaching planning, there is still room for improvement in order to highlight the relevance of translation theory in the education of future translators, providing students with the necessary means to acquire valuable and fruitful insights into the theoretical dimension of translation.

\section{References}

Agost, R. (2008). Enseñar la teoría de la traducción: diseño de competencias y explotación de recursos pedagógicos. Quaderns. Revista de Traducció, 15, 137-152.

Agost, R. \& Ordóñez-López, P. (2015). Translation Theory: Myths, Prejudices and Realities, Babel, 61 (3), 361-380.

Agost, R. \& Ordóñez-López, P. (2016). Revisión crítica del planteamiento curricular de las materias teóricas desde la visión del alumnado. Puentes entre la Traductología y el aula. III Congreso Internacional DIDTRAD, UABa, July 8, 2016.

ANECA (2013). Guía de apoyo para la redacción, la puesta en práctica y la evaluación de los resultados del aprendizaje. ANECA: Madrid. Retrieved January, 24, 2017, from http://www.aneca.es/Sala-de-prensa/Noticias/2013/ANECA-presenta-la-Guia-para-laredaccion-y-evaluacion-de-los-resultados-del-aprendizaje.

Delisle, J. (1981). L'Enseignement de l'interprétation et de la traduction. De la théorie à la pédagogie : réflexions méthodologiques. Ottawa: Éditions de l'université d'Ottawa.

Gile, D. (1995). Basic Concepts and Models for Interpreter and Translator Training. Amsterdam/Philadelphia: John Benjamins.

Gile, D. (2010). Why Translation Studies Matters: A Pragmatist's Viewpoint. In D. Gile, G. Hansen \& Pokorn, N.K. (Eds.). Why Translation Studies Matters (pp. 251-262). Amsterdam/Philadelphia: John Benjamins.

Malmkjær, K. (2006). Teaching Translation. Retrieved November 10, 2013, from https://www.llas.ac.uk//resourcedownloads/2421/malmkjaer.doc.

Mossop, B. (2003). What should be taught at translation school. Retrieved November 10, 2013, from http://isg.urv.es/publicity/isg/publications/innovation_2003/index.htm.

Ordóñez López, P. \& Agost, A. (2014). An Empirical Study of Students' Views on Theoretical Subjects: The Role of Theory in Translation Degrees at Spanish Universities. In Dans Cui, Y. \& Zhao, W. (eds.). Handbook of Research on Teaching Methods in Language Translation and Interpretation, Hershey, PA: IGI Global, 324345.

Vega, M.A. \& Pulido, M. (2013). The History of Translation and of the Theory of Translation in the Context of Translation Studies. MonTI: Monograhs on Translation and Interpreting, 1, 39-70. 